\title{
ANALISIS GAYA BELAJAR SERTA PENGARUH TERHADAP HASIL BELAJAR MATEMATIKA SISWA SELAMA PANDEMI COVID-19
}

\author{
Oleh : \\ Kristin Pardede ${ }^{1}$, Marzuki Ahmad², Muhammad Syahril Harahap ${ }^{3}$ \\ Program Studi Pendidikan Matematika Fakultas Pendidikan MIPA \\ Institut Pendidikan Tapanuli Selatan
}

\begin{abstract}
Abstrak
Penelitian ini bertujuan untuk mengetahui gaya belajar siswa dan kaitan gaya belajar siswa terhadap hasil belajar matematika siswa di lingkungan $\mathrm{V}$, kelurahan losung selama pandemi covid-19. Terdapat tiga tipe gaya belajar yang akan dibahas dalam penelitian ini, yaitu auditorial, visual dan kinestetik. Metode yang digunakan adalah metode kualitatif. Angket tertutup, wawancara tidak terstruktur, dan dokumentasi digunakan dalam pengumpulan data. Teknik Miles dan Huberman digunakan dalam pengumpulan data meliputi 1) reduksi data, 2) penyajian data, dan 3) verifikasi data. Hasil penelitian yang diperoleh menunjukkan bahwa siswa SMP di lingkungan $\mathrm{V}$ dalam pembelajaran matematika dominan memiliki gaya belajar visual dengan jumlah 5 orang (50\%) dengan nilai rata-rata 77,6. Gaya belajar auditorial dengan jumlah 2 orang (20\%) dengan nilai rata-rata 70, sedangkan gaya belajar kinestetik dengan jumlah 3 orang (30\%) dengan nilai rata-rata 56,6. Selama pandemi covid-19 siswa dengan gaya belajar visual hasil belajarnya lebih baik dibandingkan siswa dengan gaya belajar auditorial dan kinestetik.
\end{abstract}

\section{Kata kunci : Auditorial, Gaya Belajar, Hasil Belajar Matematika, Kinestetik, Visual.}

\section{Abstract}

This study aims to find out the learning style of students an the relationship of students learning style to the results of students' mathematics learning in the $V$ neighborhood, losung village during the covid-19 pandemic. There are three types of learning styles that will be discussed in this study, namely auditorial visual and kinesthetic. The method used is qualitative method. Closed questionnaire, unstructured interviews, and documentation are used in data collection. Miles and Huberman tecniques are used in data collection, include 1) data reduction, 2) data presentation, and 3) data verification. The result showed that junior high school students in environment $V$ in mathematics learning dominantly have a visual learning style with a total of 5 people (50\%) with an average rating of 77.6. Auditorial learning style with a total of people (20\%) with an average score of 70, while kinesthetic learning style with a total of peopl (30\%) with an averag rating of 56.6. During the covid-19 pandemic students with visual learning styles learn better than students with auditorial and kinesthetic learning styles.

\section{Keywords : Auditorial, Learning Style, Mathematics Learning Outcomes, Kinesthetic, Visual.}

\section{PENDAHULUAN}

Pendidikan merupakan hal yang sangat penting dalam kehidupan manusia. Pendidikan sebagai usaha manusia untuk menumbuhkan dan mengembangkan potensi-potensi yang ada dalam diri manusia, melalui pendidikan manusia mengalami proses membimbing, melatih dan memandu diri supaya terhindar atau keluar dari kebodohan dan pembodohan. Pada proses pendidikan dimana pembelajaran terjadi saat pendidik dan peserta didik memiliki komunikasi dua arah. Terjadinya pembelajaran merupakan proses dimana pendidik akan menerapkan suatu pembelajaran dikelas, dimana proses pembelajaran yang dilakukan tentunya memiliki tujuan yang ingin dicapai.

Matematika adalah salah satu cabang ilmu pengetahuan yang memegang peranan penting dalam kehidupan manusia. Hampir seluruh ilmu pengetahuan dan teknologi menggunakan matematika seperti akuntansi, kimia, fisika, ekonomi, dll. Alasan lain yang mendukung 
matematika menduduki peranan penting dalam pendidikan dapat dilihat dari jam pelajaran sekolah yang lebih banyak dibandingkan pelajaran lain.

Pembelajaran matematika disekolah perlu ditekankan agar hasil belajar yang diperoleh relevan dengan kehidupan sehari-hari dan dapat diaplikasikan sesuai dengan kebutuhan. Sudjana (dalam Chania, 2016:80) menyatakan pengertian hasil belajar adalah kemampuan-kemampuan yang dimiliki siswa. Hasil belajar peserta didik merupakan perolehan akhir dari proses pembelajaran, dimana hasil belajar sangat berperan penting dalam proses pembelajaran, karena pendidik dapat melihat ataupun mengetahui sampai sejauh mana keberhasilan pembelajaran yang sudah diterapkan.

Adanya pandemi Covid 19, tidak hanya mempengaruhi sistem ekonomi di Indonesia, akan tetapi berpengaruh secara global di semua sektor kehidupan manusia. Tidak terkecuali di ranah pendidikan. Agar sistem pembelajaran terus berlangsung, pemerintah melalui Kementrian Pendidikan dan Kebudayaan melakukan upaya penanganan, sehingga proses pembelajaran tetap berjalan. Pelaksanaan pembelajaran daring yang selama ini digunakan sebagai pendamping metode pembelajaran didalam kelas, pada masa pandemi ini harus menjadi metode pembelajaran utama demi tetap terlaksananya proses belajar mengajar, yang tentunya berpengaruh dengan hasil belajar siswa di masa pandemi covid-19.

Berdasarkan hasil observasi yang dilakukan peneliti pada tanggal 05 februari 2021 di lingkungan V, kelurahan losung, kecamatan Padangsidimpuan Selatan, kota Padangsidimpuan diperoleh sebagian nilai masih dibawah Kriteria Ketuntasan Minimal (KKM) yang ditetapkan sekolah yaitu 75, dimana 3 dari 10 orang yang lulus KKM (30\%) dan 7 dari 10 orang siswa yang tidak lulus KKM (70\%). Dengan nilai rata-rata kelas 69,1. Maka dari itu peneliti menyimpulkan bahwa hasil belajar matematika siswa di lingkungan $\mathrm{V}$, kelurahan losung, kecamatan Padangsidimpuan Selatan, kota Padangsidimpuan berada pada kategori yang belum baik. Hal ini dikarenakan persentase siswa yang lulus KKM dan nilai rata-rata kelas belum memenuhi kriteria hasil belajar yang berhasil.

Berdasarkan hasil wawancara pada observasi awal yang dilakukan peneliti di lingkungan V, kelurahan losung, kecamatan Padangsidimpuan Selatan, kota Padangsidimpuan dengan beberapa orangtua siswa, diperoleh hasil belajar rendah dikarenakan siswa tidak memahami materi yang diberikan oleh guru. Hal ini terjadi karena siswa hanya belajar melalui aplikasi whatsapps dan materi yang diberikan hanya berbentuk dokumen, tanpa adanya penjelasan secara rinci, sehingga siswa mencari sumber belajar lain yang mudah dan praktis, seperti aplikasi google, dimana siswa dengan mudahnya dapat menyelesaikan tugas yang diberikan tanpa memahami materi.

Dilihat dari hasil belajar siswa dapat diperhatikan bahwa banyak faktor yang mempengaruhinya, salah satunya yaitu gaya belajar. Ketika menyampaikan sebuah pengetahuan atau ilmu, seorang pendidik dituntut untuk memahami gaya belajar setiap peserta didik. Perlu disadari bahwa setiap peserta didik memiliki karakter yang berbeda dalam menyerap, mengolah, dan mengembangkan cara belajar dan daya pikirnya menyelesaikan sebuah permasalahan yang dihadapi. Salah satu karakteristik belajar yang berkaitan dengan menyerap, mengolah, dan mengembangkan cara belajar serta daya pikir adalah gaya belajar peserta didik. Gaya belajar merupakan cara seseorang menerima informasi baru dan proses yang akan digunakan untuk belajar. Gaya belajar peserta didik dalam memahami mata pelajaran matematika sangat diperlukan karena mata pelajaran matematika memerlukan pemahaman konsep, teori, dan perhitungan rumus.

Hal ini didukung oleh pendapat Nurhazannah pada tahun 2020 dengan judul " Analisis Hasil Belajar Matematika Siswa Ditinjau dari Gaya Belajar Siswa di SMP-IT BUNAYYA Padangsidimpuan" dengan hasil penelitian gaya belajar peserta didik sangat penting bagi guru untuk mengetahui bagaimana menerapkan strategi, dan metode pembelajaran yang sesuai dengan peserta didiknya. Maka dari itu guru harus menerapkan strategi pembelajaran yang berbeda dan kreatif. Berdasarkan uraian tersebut, sehingga diperoleh pandangan bahwa hasil belajar siswa sangat penting dalam proses pembelajaran, dimana hasil belajar ditentukan oleh beberapa faktor, salah satu faktornya yaitu gaya belajar, maka oleh karena itu gaya belajar perlu di analisis.

Setiap manusia memiliki cara yang berbeda dalam menyerap dan mengolah informasi yang diterima, hal ini sangat berkaitan dengan gaya belajar masing-masing individu. Gaya belajar merupakan cara termudah yang dimiliki oleh individu dalam menyerap, mengatur, dan mengolah informasi yang diterima. Gaya belajar yang sesuai adalah kunci keberhasilan siswa dalam belajar (Bire, 2014:169). Hasil belajar siswa dipengaruhi oleh beberapa faktor. Faktor-faktor yang mempengaruhi hasil belajar menurut Ruseffendi (dalam sutrisno, 2013) menyatakan : 
Ada 2 faktor yang dapat mempengaruhi hasil belajar yaitu:

a) Faktor dari dalam, meliputi:

1) Kecerdasan anak

2) Kesiapan anak (perkembangan mental sudah siap dan pengetahuan prasyaratnya telah dimiliki)

3) Bakat anak

4) Kemauan belajar

5) Minat belajar.

b) Faktor dari luar yang dapat mempengaruhi hasil belajar siswa meliputi :

1) Model penyajian materi pembelajaran

2) Pribadi dan sikap guru

3) Suasana pengajaran

4) Kompetensi guru

5) Kondisi masyarakat luar.

\section{METODE PENELITIAN}

Penulis menggunakan metode penelitian kualitatif. Sebuah penelitian kualitatif terdapat objek penelitian dan informan penelitian yang dimana keduanya saling berkesinambungan. Spradley (dalam sugiyono, 2013:229) menyatakan "Objek penelitian dalam penelitian kualitatif dinamakan situasi sosial, yang terdiri dari tiga elemen yaitu tempat (place), pelaku (Actors), aktivitas (Activity) yang berinteraksi secara sinergis”. Situasi sosial tersebut dapat dinyatakan sebagai objek penelitian yang ingin diketahui "apa yang terjadi di dalamnya". Adapun objek peneliti ini adalah siswa SMP di lingkungan V, kelurahan losung, kecamatan Padangsidimpuan Selatan, kota Padangsidimpuan. Informan penelitian merupakan orang yang menguasai data dan informasi dari suatu objek penelitian. Oleh karena itu peneliti menetapkan informan dalam penelitian ini adalah orangtua siswa SMP di lingkungan V, kelurahan losung, kecamatan Padangsidimpuan Selatan, kota Padangsidimpuan.

Peneliti menggunakan teknik pengumpulan data melalui angket, wawancara dan dokumentasi. Peneliti menggunakan angket tertutup sebagai teknik pengumpulan data untuk mendapatkan gaya belajar, peneliti menggunakan wawancara tidak terstruktur (unstructured interview), Peneliti mengumpulkan dokumen berupa tulisan, gambar, buku, jurnal dan dokumen lainnya. Penelitian ini menggunakan dokumen berupa foto saat wawancara, foto saat pengisian angket, jurnal sebagai referensi, lembar hasil wawancara dan angket. Gaya belajar dibagi dalam beberapa bagian, adapun kesimpulan tersebut sebagai berikut :

Tabel 1. Jenis dan Indikator Gaya Belajar

\begin{tabular}{ll}
\hline NO & \multicolumn{1}{c}{ Jenis dan Indikator Gaya Belajar } \\
\hline A. & Gaya Belajar Auditorial \\
\hline 1. & Suka berbicara kepada diri sendiri ketika bekerja. \\
\hline 2. & Lebih mudah mengingat dengan mendengar daripada mengamati diskusi. \\
\hline 3. & Biasanya ia pembicara yang fasih. \\
\hline 4. & Lebih mahir mengeja dengan keras daripada menuliskannya. \\
\hline B. & Gaya Belajar Visual \\
\hline 1. & Lebih suka seni rupa. \\
\hline 2. & Lebih suka membaca daripada dibacakan. \\
\hline 3. & Mengingat yang dilihat,daripada yang didengar. \\
\hline 4. & Mempunyai masalah untuk mengingat instruksi verbal, kecuali jika ditulis, dan seringkali \\
\hline C. & minta bantuan orang untuk mengulangnya. \\
\hline 1. & Mudah belajar dengan memanipulasi dan praktik. \\
\hline 2. & Menyertakan jari untuk sebagai penunjuk ketika membaca. \\
\hline 3. & Membaca buku dengan memeragakannya dengan gerakan tubuh. \\
\hline 4. & Menyentuh orang untuk mendapatka perhatian mereka. \\
\hline
\end{tabular}


ISSN. 2621-9832

JURNAL MathEdu (Mathematic Education Journal) http://journal.ipts.ac.id/index.php/MathEdu

Vol. 4 No. 2 Juli 2021

(Wassahua, 2016)

Adapun kisi-kisi angket yang diberikan adalah sebagai berikut :

Tabel 2. Kisi-kisi Angket Gaya Belajar Siswa SMP lingkungan V, kelurahan Losung

\begin{tabular}{llcl}
\hline No & Indikator & Item Soal & Jumlah Soal \\
\hline 1 & Auditorial & $1,2,3,4,5,6,7,8,9,10$ & \multirow{2}{*}{30} \\
\cline { 1 - 3 } 2 & Visual & $11,12,13,14,15,16,17,18,19,20$ & \\
\hline 3 & Kinestetik & $21,22,23,24,25,26,27,28,29,30$ & \\
\hline
\end{tabular}

Angket gaya belajar siswa ini terdiri dari 30 item soal dan memuat 3 item pilihan jawaban, yaitu : selalu, kadang-kadang, dan jarang. Setiap item soal memiliki skor yang berbeda-beda sesuai dengan jawaban yang dipilih, seperti pada tabel berikut :

Tabel 3. Penskoran Hasil Angket Gaya Belajar

\begin{tabular}{lccl}
\hline No & Skor & Alternatif Jawaban & \multicolumn{1}{c}{ Nomor Item } \\
\hline 1 & 2 & Sering & $1,2,3,4,5,6,7,8,9,10,11,12,13,14$, \\
\hline 2 & 1 & Kadang-kadang & $15,16,17,18,19,20,21,22,23,24,25$, \\
\hline 3 & 0 & Jarang & $26,27,28,29,30$. \\
\hline
\end{tabular}

Arikunto (2009)

Untuk memperoleh hasil penelitian yang benar-benar dan dapat di pertanggungjawabkan dari segala hal, maka peneliti harus melaksanakan pemeriksaan terhadap keabsahan data dari proses penelitian dalam mendapatkan data. Menurut Sondak (2019:676) untuk menentukan keabsahan data perlu adanya teknik pemeriksaan yang berdasar sejumlah kriteria tertentu.

Keabsahan ini juga dapat dicapai dengan proses pengumpulan data yang tepat, salah satu caranya adalah dengan triangulasi, yaitu teknik pemeriksaan keabsahan data yang memanfaatkan sesuatu yang lain untuk keperluan atau sebagai pembanding terhadap data. Teknik triangulasi yang digunakan dalam penelitian ini adalah triangulasi sumber, dimana triangulasi sumber ini mengarahkan peneliti untuk mengumpulkan data dari beragam sumber yang tersedia. Membandingkan perolehan data pada tenik yang berbeda dalam fenomena yang sama.

Setiap penelitian memerlukan analisis data. Bogdan dan Biklen (dalam Yaumi dan Damopolii, 2014:132) menyatakan bahwa analisis data adalah proses pencarian dan penyusunan secara sistematis terhadap wawancara, catatan lapangan, dan bahan lainnya. Adapun proses analisis data penelitian adalah Analisis sebelum dilapangan, dan Analisis di lapangan Model Miles dan Huberman. Aktivitas dalam analisis data, yaitu :

a. Reduksi Data

Langkah awal yaitu reduksi data. Reduksi data adalah menyeleksi, menyederhanakan, mengubah bentuk data yang terdapat pada catatan lapangang tanpa mengurangi esensi makna yang terkandung didalamnya (Yaumi dan Damopolii, 2014:138). Menurut Ahmad (2018:88) Reduksi data merupakan langkah awal dalam menganalisa data untuk mempermudah pemahaman peneliti terhadap data yang terkumpul.

Reduksi data yaitu merangkum, menyeleksi, memfokuskan, memilih data-data yang pokok dan penting. Pada penelitian ini data diperoleh dengan angket dan wawancara, dimana kegiatan yang dilakukan dalam wawancara adalah membuat rekaman hasil wawancara setiap subjek penelitian. Rekaman hasil wawancara subjek dipadukan dengan catatan-catatan selama wawancara.

b. Penyajian Data

Setelah data di reduksi, langkah selanjutnya adalah penyajian data atau mendisplay data. Penyajian data adalah penulisan kembali informasi yang terorganisasi dan terkategori. Ahmad dan Nasution (2018:88). Dalam penelitian kualitatif penyajian data bisa dilakukan dalam bentuk uraian singkat, bagan, teks yang bersifat naratif (Sugiyono, 2013:249).

c. Kesimpulan (Conclusions) 
ISSN. 2621-9832

JURNAL MathEdu (Mathematic Education Journal) http://journal.ipts.ac.id/index.php/MathEdu

Vol. 4 No. 2 Juli 2021

Langkah ke tiga dalam analisis data kualitatif menurut Miles dan Huberman adalah penarikan kesimpulan dan verifikasi. Kesimpulan dalam penelitian kualitatif adalah "merupakan temuan baru yang sebelumnya belum pernah ada" (Sugiyono, 2013:253). Penarikan kesimpulan yang dilakukan berdasarkan data yang dikumpulkan, baik melalui angket maupun wawancara dan catatan lapangan.

\section{HASIL DAN PEMBAHASAN}

Data mengenai gaya belajar didapat melalui penyebaran angket dan wawancara. Pengambilan data angket dan wawancara dilaksanakan di bulan maret 2021. Data mengenai hasil belajar siswa diambil dari nilai hasil belajar yang paling dekat dengan pengisian angket, yaitu nilai ulangan mid semester ganjil 2020/2021. Hasil rekap nilai dan data angket dapat dilihat pada tabel berikut :

Tabel 4. Rekap nilai hasil dari angket gaya belajar siswa SMP lingkungan V, kelurahan Losung

\begin{tabular}{|c|c|c|c|c|c|c|c|c|}
\hline \multirow[t]{2}{*}{ NO } & \multirow{2}{*}{$\begin{array}{l}\text { Nama } \\
\text { Siswa }\end{array}$} & \multicolumn{6}{|c|}{ Jawaban Nilai } & \multirow[t]{2}{*}{ Jumlah } \\
\hline & & Sering & Kadang-Kadang & Jarang & 2 & 1 & $\mathbf{0}$ & \\
\hline 1 & DG & 10 & 14 & 6 & 20 & 14 & 0 & 34 \\
\hline 2 & DJ & 13 & 13 & 4 & 26 & 13 & 0 & 39 \\
\hline 3 & $\mathrm{EF}$ & 14 & 8 & 9 & 28 & 8 & 0 & 36 \\
\hline 4 & GD & 2 & 13 & 15 & 4 & 26 & 0 & 30 \\
\hline 5 & GE & 3 & 19 & 8 & 6 & 19 & 0 & 25 \\
\hline 6 & GR & 6 & 18 & 6 & 12 & 18 & 0 & 30 \\
\hline 7 & $\mathrm{OJ}$ & 12 & 7 & 11 & 24 & 7 & 0 & 31 \\
\hline 8 & $\mathrm{RD}$ & 6 & 13 & 11 & 12 & 13 & 0 & 25 \\
\hline 9 & RM & 10 & 16 & 4 & 20 & 16 & 0 & 36 \\
\hline \multirow[t]{2}{*}{10} & $\mathrm{SC}$ & 5 & 16 & 9 & 10 & 16 & 0 & 26 \\
\hline & & & Jumlah & & & & & 312 \\
\hline
\end{tabular}

Tabel 5. Rekap data hasil dari angket gaya belajar siswa SMP lingkungan V, kelurahan Losung

\begin{tabular}{llccc}
\hline No & Nama Siswa & Auditorial & Visual & Kinestetik \\
\hline & & & $\sqrt{ }$ & \\
\hline 1 & DG & & & $\sqrt{ }$ \\
\hline 2 & DJ & $\sqrt{ }$ & \\
\hline 3 & EF & & $\sqrt{ }$ & $\sqrt{ }$ \\
\hline 4 & GD & & & \\
\hline 5 & GE & & & \\
\hline 6 & GR & & $\sqrt{ }$ \\
\hline 7 & OJ & $\sqrt{ }$ & \\
\hline 8 & RD & & $\sqrt{ }$ & \\
\hline 9 & RM & SC & & \\
\hline 10 & & & & \\
\hline
\end{tabular}

Berdasarkan uraian di atas, siswa menunjukkan gaya belajar auditorial, visual dan kinestetik. Adapun gaya belajar yang dominan berdasarkan angket adalah gaya belajar visual. Berikut merupakan persentasi hasil angket siswa SMP di lingkungan V, kelurahan Losung :

1. Auditorial $=\frac{2}{10} \times 100=20 \%$

2. Visual $=\frac{5}{10} \times 100=50 \%$

3. Kinestetik $=\frac{3}{10} \times 100=30 \%$

Persentase hasil dari angket gaya belajar siswa SMP di lingkungan V, kelurahan losung dalam bentuk diagram batang, sebagai berikut : 


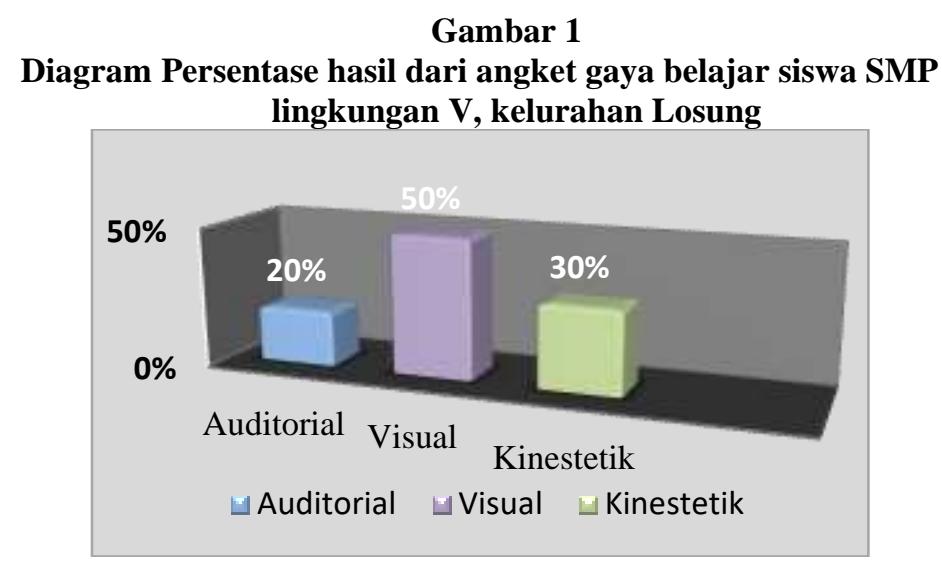

Besarnya persentase hasil angket gaya belajar siswa SMP di lingkungan V, kelurahan Losung yang didapatkan yaitu gaya belajar visual dengan $50 \%$ yang berjumlah 5 orang siswa, gaya belajar auditorial memiliki 20\% dengan jumlah 2 orang siswa, dan gaya belajar kinestetik $30 \%$ dengan jumlah 3 orang siswa. Sehingga dapat disimpulkan bahwa kecenderungan gaya belajar siswa SMP di lingkungan $\mathrm{V}$, kelurahan Losung adalah gaya belajar visual.

Data mengenai hasil belajar siswa diambil dari nilai hasil belajar yang paling dekat dengan pengisian angket, yaitu nilai ulangan mid semester ganjil 2020/2021. Adapun hubungan gaya belajar terhadap hasil belajar siswa SMP lingkungan V, kelurahan losung adalah sebagai berikut:

- Hasil belajar siswa auditorial dapat dilihat pada tabel dibawah ini:

Tabel 6. Hasil Belajar Siswa Auditorial

\begin{tabular}{|c|c|c|}
\hline No & Nama Siswa & Nilai Ulangan \\
\hline 1 & $\mathrm{EF}$ & 68 \\
\hline 2 & $\mathrm{RD}$ & 72 \\
\hline \multicolumn{2}{|c|}{ Rata-rata } & 70 \\
\hline
\end{tabular}

Dari tabel di atas dapat dilihat bahwa nilai ulangan siswa SMP lingkungn V, kelurahan Losung yang memiliki gaya belajar auditorial dengan nilai EF 68 tidak tuntas dan RD 72 tidak tuntas, dengan rata-rata nilai 70. Dari hasil angket dan wawancara yang dilakukan peneliti, siswa yang memiliki gaya belajar auditorial senang mendengarkan oranglain berbicara, belajar melalui mendengar dan mengingat, serta senang mendengarkan materi yang disampaikan guru dengan bercerita.

- Hasil belajar siswa visual dapat dilihat pada tabel dibawah ini :

Tabel 7. Hasil Belajar Siswa Visual

\begin{tabular}{lcc}
\hline No & Nama Siswa & Nilai Ulangan \\
\hline 1 & DG & 50 \\
\hline 2 & GD & 100 \\
\hline 3 & GE & 100 \\
\hline 4 & RM & 50 \\
\hline 5 & SC & 88 \\
\hline & Rata-rata & 77,6 \\
\hline
\end{tabular}

Dari tabel di atas dapat dilihat bahwa nilai ulangan siswa SMP lingkungn V, kelurahan Losung yang memiliki gaya belajar visual dengan nilai DG 50 tidak tuntas, GD 100 tuntas, GE 100 tuntas, RM 50 tidak tuntas, dan SC 88 tuntas, dengan rata-rata nilai 77,6. Dari hasil angket dan wawancara yang peneliti lakukan, siswa yang memiliki gaya belajar visual lebih senang belajar dengan melihat contoh-contoh gambar, lebih mengingat apa yang dilihat, dan rata-rata sebelum melakukan suatu kegiatan terlebih dahulu direncanakan. 
ISSN. 2621-9832

JURNAL MathEdu (Mathematic Education Journal) http://journal.ipts.ac.id/index.php/MathEdu

Vol. 4 No. 2 Juli 2021

- Hasil belajar siswa kinestetik dapat dilihat pada tabel dibawah ini :

Tabel 8. Hasil Belajar Siswa Kinestetik

\begin{tabular}{|c|c|c|}
\hline No & Nama Siswa & Nilai Ulangan \\
\hline 1 & DJ & 60 \\
\hline 2 & OD & 60 \\
\hline 3 & GR & 50 \\
\hline \multicolumn{2}{|c|}{ Rata-rata } & 56,6 \\
\hline
\end{tabular}

Dari tabel di atas dapat dilihat bahwa nilai ulangan siswa SMP lingkungn V, kelurahan Losung yang memiliki gaya belajar kinestetik dengan nilai DJ 60 tidak tuntas, OD 60 tidak tuntas, dan GR 50 tidak tuntas, dengan rata-rata nilai 56,6. Dari hasil angket dan wawancara yang peneliti lakukan, siswa yang memilki gaya belajar kinestetik lebih senang belajar dengan cara bergerak, yaitu belajar dengan melakukan menanggapi dengan fisik seperti belajar dengan praktek, sering melakukan kegiatan fisik dan tidak bisa diam dengan waktu yang lama.

\section{Gaya Belajar}

Gaya belajar siswa adalah suatu cara belajar yang dimiliki oleh setiap siswa dalam menyerap, mengatur dan mengolah informasi yang dilihat dan dialami dalam proses pembelajaran. Gaya belajar siswa tersebut merupakan kunci keberhasilan siswa dalam proses pembelajaran. Hasil penelitian gaya belajar siswa dalam pembelajaran matematika yang dilakukan peneliti pada siswa SMP di lingkungan V, kelurahan Losung dari data hasil angket menunjukkan bahwa gaya belajar yang lebih dominan yaitu gaya belajar visual. Hal ini diperkuat dengan hasil wawancara siswa yang peneliti lakukan.

Persentase hasil angket gaya belajar siswa SMP di lingkungan V, kelurahan Losung yang didapatkan yaitu gaya belajar visual dengan $50 \%$ yang berjumlah 5 orang siswa, gaya belajar auditorial memiliki $20 \%$ dengan jumlah 2 orang siswa, dan gaya belajar kinestetik $30 \%$ dengan jumlah 3 orang siswa. Sehingga dapat disimpulkan bahwa kecenderungan gaya belajar siswa SMP di lingkungan $\mathrm{V}$, kelurahan Losung adalah gaya belajar visual.

Berbeda dengan hasil penelitian yang dilakukam oleh Nurhazanah R. Simanungkalit (2020) dengan judul "Analisis Belajar Matematika Siswa Ditinjau Dari Gaya Belajar Siswa Di SMP-IT Bunayya Padangsidimpuan", dengan kesimpulan gaya belajar peserta didik kelas VII-C SMP-IT Bunayya Padangsidimpuan dalam pembelajaran Matematika dominan memilik gaya belajar Kinestetik dengan jumlah 11 orang $(52,4 \%)$, gaya belajar Visual berjumlah 8 orang (38\%), sedangkan Gaya belajar Auditorial berjumlah 2 orang $(9,6 \%)$.

Hal ini bisa terjadi karena munculnya gaya belajar dipengaruhi oleh beberapa faktor. Rita Dunn (dalam Mar'ah, 2015:20) menemukan banyak variabel yang mempengaruhi gaya belajar yaitu faktor fisik, emosional, sosiologis dan faktor lingkungan. Sejalan dengan pendapat Dryden dan Vos ( dalam Julianti, 2010:17) faktor yang mempengaruhi gaya belajar adalah lingkungan fisik, kebutuhan emosional, kebutuhan sosial, dan kebutuhan biologis.

\section{Kaitan Gaya Belajar Terhadap Hasil Belajar}

Hasil belajar matematika merupakan ukuran untuk menentukan berhasil atau tidaknya seseorang dalam upaya memahami materi pelajaran matematika. Berdasarkan hasil angket dan wawancara serta dari nilai ulangan siswa SMP lingkungan V, kelurahan Losung, peneliti dapat mengetahui siswa dengan gaya belajar auditorial nilai rata-ratanya 70 , gaya belajar visual nilai rata-ratanya 77,6. Siswa dengan gaya belajar kinestetik nilai rata-ratanya 56,6.

Hasil wawancara dengan orangtua siswa mengatakan bahwa siswa tidak memahami materi yang diberikan oleh guru. Hal ini terjadi karena siswa hanya belajar melalui aplikasi whatsapps dan materi yang diberikan hanya berbentuk dokumen, tanpa adanya penjelasan secara rinci, sehingga siswa mencari sumber belajar lain yang mudah dan praktis, seperti aplikasi google, dimana siswa dengan mudahnya dapat menyelesaikan tugas yang diberikan tanpa memahami materi.

Siswa dengan gaya belajar visual lebih cenderung belajar dengan cara melihat contoh gambar dan membaca, pada saat melaksanakan pembelajaran daring, dimana pembelajaran daring ini dilakukan melalui aplikasi whatsapps dan materi yang diberikan berbentuk dokumen, dengan 
melihat dan membaca siswa bergaya belajar visual dapat memahami materi yang diberikan. Meskipun nilai rata-rata siswa bergaya belajar visual sudah tuntas, namun masih ada siswa dengan nilai ulangan yang belum tuntas yaitu DG dan RM, hal ini dikarenakan oleh beberapa faktor, yaitu siswa tersebut tidak suka dengan pelajaran matematika, pembelajaran materi yang diberikan oleh guru melalui aplikasi whatsapp hanya berupa dokumen, yang tentunya hal ini membuat siswa mudah bosan dalam mengikuti pembelajaran, ditambah lagi tidak ada nya pengawasan dari orangtua.

Sedangkan siswa dengan gaya belajar auditorial akan sulit memahami, hal ini dikarenakan siswa dengan gaya belajar auditorial lebih cenderung belajar dengan mendengarkan. Begitu pula siswa dengan gaya belajar kinestetik, siswa dengan gaya belajar kinestetik belajar dengan bergerak, menanggapi dengan fisik, lebih mudah memahami pelajaran dengan praktek, yang tentunya pembelajaran dengan materi yang diberikan berbentuk dokumen akan sulit dipahami oleh siswa bergaya belajar kinestetik. Dari hasil angket, wawancara serta nilai hasil ulangan siswa, peneliti dapat mengetahui dan membandingkan bahwa selama pandemi covid-19 ini siswa SMP lingkungan $\mathrm{V}$, kelurahan Losung dengan gaya belajar visual hasil belajarnya lebih baik dibandingkan siswa dengan gaya belajar auditorial dan kinestetik.

Hasil penelitian ini didukung oleh pendapat Sarfa Wassahua (2016) dengan judul "Analisis Gaya Belajar Siswa Terhadap Hasil Belajar Matematika Pada Materi Himpunan Siswa Kelas VII SMP Negeri Karang Jaya Kecamatan Namlea Kapubaten Buru” dengan kesimpulan gaya belajar subjek sangat menentukan keberhasilan subjek dalam proses pembelajaran matematika khususnya himpunan, dari ketiga indikator gaya belajar yang digunakan dalam penelitian ini yaitu gaya belajar auditorial, visual dan kinestetik, dimana subjek lebih cenderung ke gaya belajar visual memiliki hasil belajarnya lebih baik dibandingkan dengan subjek yang memiliki gaya belajar auditorial dan kinestetik.

Gaya belajar merupakan salah satu faktor yang dapat menentukan hasil belajar. Ni wayan ( dalam simanungkalit, 2020:17) menyebutkan faktor yang berpengaruh besar pada hasil belajar yaitu gaya belajar. Hasil belajar sangat penting dalam proses pembelajaran. Oleh karena itu, gaya belajar hendaknya diperhatikan oleh pendidik (Wardoyo et al, 2020), dalam proses pembelajaran di tengah pandemi covid-19 ini, terkhusus pada pembelajaran matematika, untuk mendapatkan hasil pembelajaran yang maksimal.

\section{KESIMPULAN}

\section{Kesimpulan}

Hasil penelitian yang diperoleh menunjukkan bahwa terdapat tiga gaya belajar yang muncul pada siswa SMP lingkungan V, kelurahan Losung yaitu auditorial, visual dan kinestetik. Dalam pembelajaran matematika siswa lebih dominan memiliki gaya belajar visual dengan jumlah 5 orang $(50 \%)$ dengan nilai rata-rata 77,6 . Gaya belajar auditorial dengan jumlah 2 orang (20\%) dengan nilai rata-rata 70, sedangkan gaya belajar kinestetik dengan jumlah 3 orang (30\%) dengan nilai rata-rata 56,6. Selama pandemi covid-19 siswa dengan gaya belajar visual hasil belajarnya lebih baik dibandingkan siswa dengan gaya belajar auditorial dan kinestetik. Hal ini dibuktikan dengan hasil angket dan wawancara yang diberikan peneliti kepada siswa, serta hasil ulangan siswa.

Sesuai dengan ciri-ciri gaya belajar visual, siswa lebih cenderung belajar dengan cara melihat contoh gambar dan membaca, dan lebih mengingat apa yang dilihat daripada yang didengar. Pada saat melaksanakan pembelajaran daring, dimana pembelajaran daring ini dilakukan melalui aplikasi whatsapps dan materi yang diberikan berbentuk dokumen, dengan melihat dan membaca siswa bergaya belajar visual dapat memahami materi yang diberikan. Sedangkan siswa dengan gaya belajar auditorial akan sulit memahami, hal ini dikarenakan siswa dengan gaya belajar auditorial lebih cenderung belajar dengan mendengarkan, lebih mudah mengingat dengan mendengar, dan merupakan pembicara yang fasih. Begitu pula siswa dengan gaya belajar kinestetik, siswa dengan gaya belajar kinestetik belajar dengan bergerak, menanggapi dengan fisik, lebih mudah memahami pelajaran dengan praktek, menyentuh oranglain untuk mendapatkan perhatian, yang tentunya pembelajaran dengan materi yang diberikan berbentuk dokumen akan sulit dipahami oleh siswa bergaya belajar kinestetik. 


\section{Implikasi}

Setiap individu memiliki gaya belajar yang berbeda, hal ini merupakan cara untuk mengolah informasi yang diterima. Mengetahui gaya belajar peserta didik tentunya sangat penting bagi tenaga pendidik untuk mengetahui bagaimana cara menerapkan strategi dan metode pembelajaran yang sesuai dengan peserta didik agar hasil belajar yang didapatkan maksimal.

Di tengah pandemi covid-19 pada saat ini, dimana pembelajaran dilaksanakan secara daring, oleh karena itu sebagai tenaga pendidik harus menerapkan strategi pembelajaran yang berbeda dan kreatif sesuai dengan gaya belajar peserta didik, agar peserta didik mampu mengikuti kegiatan pembelajaran yang berlangsung, peran orangtua sebagai pendamping anak pada pembelajaran daring saat ini juga sangat diperlukan, untuk itu orangtua juga hendaknya mengetahui gaya belajar yang dimiliki anak. Dengan demikian, perbedaan gaya belajar yang dimiliki peserta didik diharapkan mampu diakomodasikan dengan baik. Sehingga mendapatkan hasil belajar yang maksimal.

\section{Saran}

Berdasarkan pembahasan dan kesimpulan hasil penelitian, maka penulis menyarankan beberapa hal berikut :

1. Bagi tenaga pendidik perlu dilakukan pendekatan yang lebih tepat kepada siswa-siswa agar mereka dapat lebih tertarik pada pembelajaran matematika. Memperhatikan karateristik gaya belajar siswa, sehingga tenaga pendidik tidak memaksa gaya belajar yang kurang sesuai dengan gaya belajar yang dimiliki siswa. Metode pembelajaran diperbanyak terhadap pendekatan gaya belajar siswa. Tenaga pendidik hatus terampil dan kreatif serta memanfaatkan sarana dan prasarana yang ada.

2. Bagi orangtua perlu mengetahui dan memahami gaya belajar anak, sehingga proses pembelajaran dirumah dapat dilaksanakan dengan baik.

3. Bagi siswa hendaknya mengetahui gaya belajar sendiri, sehingga mampu meningkatkan prestasi belajar. Memaksimalkan gaya belajar yang dimiliki saat proses belajar mengajar.

4. Bagi peneliti selanjutnya, agar lebih banyak lagi menggunakan teknik pengumpulan data, hal ini dimaksudkan agar hasil penelitian lebih baik.

\section{REFERENSI}

Ahmad, M dan Nasution, D, P. (2018). Analisis Kualitatif Kemampuan Komunikasi Matematis Siswa yang Diberi Pembelajaran Matematika Realistik. Jurnal Gantang, III (2), 83-95.

Arikunto, S. (2009). Manajemen Penelitian. Jakarta: Rineka Cipta.

Bire, A, L., Geradus, U., dan Bire, J. (2014). Pengaruh Gaya Belajar Visual, Auditorial, Dan Kinestetik Terhadap Prestasi Belajar. Jurnal Kependidikan, 44(2), 168-174.

Julianti, I, A, R. (2016). Analisis Karakteristik Gaya belajar siswa Dalam Pembelajaran IPS kelas V SDN di Kecamatan Godong Kabupaten Grobogan. Skripsi, Jurusan Pendidikan Guru Sekolah Dasar, Universitas Negeri Semarang.

Mar'ah, Annisatul. (2015). Gaya Belajar dan Faktor Pengaruhnya Terhadap Pencapaian Prestasi Belajar IPA Terpadu siswa Kelas VIII Mts Sultah Fatah Gaji Guntur Demak Tahun Pelajaran 2015/2016. Skripsi, UIN Walisongo.

M, Chania, Y., Haviz, M., dan Sasmita, D. (2016). Hubungan Gaya Belajar Dengan Hasil Belajar Siswa Pada Pembelajaran Biologi Kelas X SMAN 2 Sungai Tarab Kabupaten Tanah Datar. Jurnal of Saintek, 8 (1), 77-84.

Simanungkalit, N, R., Elindra, R., dan Ardiana, N. (2020). Analisis Hasil Belajar Matematika Siswa Ditinjau dari Gaya Belajar Siswa di SMP_IT BUNAYYA Padangsidimpuan. Jurnal MathEdu (Mathematic Education Journal), 3( 3), 59-66.

Sugiyono. (2013). Metode Penelitian Kuantitaif Kualitatif Dan R\&D. Bandung: Alfabeta.

Sutrisno, B. (2013). Peningkatan Hasil Belajar Siswa Dalam Pembelajaran Matematika Dengan Menggunakan Teropong Pecahan di Kelas V Sekolah Dasar. Artikel Penelitian.

Sondak, S, H., Taroreh, R, N., dan Uhing, Y. (2019). Faktor-faktor Loyalitas Pegawai di Dinas Pendidikan Daerah Provinsi Sulawesi utara. Jurnal EMBA, 7(1), 671-680. 
ISSN. 2621-9832

JURNAL MathEdu (Mathematic Education Journal)

http://journal.ipts.ac.id/index.php/MathEdu

Vol. 4 No. 2 Juli 2021

Wardoyo, C., Herdiani, A., Susilowati, N., dan Harahap, M, S. (2020). Profesionalism and Profesionalization Of Early Stage Teachers in Higher Education. Journal of Applied Research in Higher Education, 12 (5), 1175-1187.

Wassahua, S. (2016). Analisis Gaya Belajar Siswa Terhadap Hasil Belajar Matematika Pada Materi Himpunan Siswa Kelas VII SMP negeri Karang Jaya Kecamatan Namlea Kabupaten Buru. Jurnal Matematika Dan Pembelajarannya, 2( 1), 84-103.

Yaumi, M dan Damopolii, M. (2014). Action Research teori, model dan Aplikasi. Jakarta: Kencana. 